\title{
Effect of the antioxidant profile in the diet of farmed coho salmon (Oncorhynchus kisutch) on the nutritional value retention during frozen storage
}

\author{
By J. Ortiz ${ }^{1}$, M.A. Larraín ${ }^{1}$, N. Pacheco ${ }^{1}$, J.P. Vivanco ${ }^{1}$ and S.P. Aubourg ${ }^{2, *}$ \\ ${ }^{1}$ Department of Food Science and Chemical Technology. Facultad de Ciencias Químicas y Farmacéuticas. \\ Universidad de Chile. Santiago (Chile) \\ ${ }^{2}$ Department of Food Technology. Instituto de Investigaciones Marinas (CSIC). Vigo (Spain) \\ * Corresponding author: saubourg@iim.csic.es
}

\section{RESUMEN}

Efecto de la composición en antioxidants incluidos en la dieta sobre la retención del valor nutricional de salmón coho (Oncorhynchus kisutch) de cultivo durante su conservación en congelación

Salmones coho (Oncorhynchus kisutch) fueron alimentados con una dieta enriquecida en antioxidantes sintéticos (butil-hidroxi-tolueno y etoxiquina, dieta I) y su efecto comparado con dos dietas enriquecidas en antioxidantes naturales (una mezcla rica en isómeros de tocoferol, dieta II; una mezcla de isómeros de tocoferol y extracto de romero, dieta III). Una vez sacrificado, el pescado fue conservado a $-18^{\circ} \mathrm{C}$ durante 18 meses. El empleo de la dieta II llevó a muestras congeladas con contenido superior en proteínas sarcoplásmicas y en $\gamma$ - y $\delta$-tocoferol al ser comparados con pescado previamente alimentado con la dieta I. Sin embargo, no se observaron diferencias a nivel de composición proximal, contenido en $\alpha$-tocoferol y astaxantina y parámetros de color ( $L^{*}$, $\left.a^{*}, b^{\star}\right)$. A nivel de composición en ácidos grasos, los individuos correspondientes a la dieta II reflejaron mayores contenidos en C22:6 $\omega 3$ y monoinsaturados, pero menores en C20:5 $\omega 3$ y saturados al ser comparados con sus homólogos de la dieta I.

PALABRAS CLAVE: Ácidos grasos - Antioxidantes Composición elemental - Conservación en congelación Dieta - Oncorhynchus kisutch.

\section{SUMMARY}

Effect of the antioxidant profile in the diet of farmed coho salmon (Oncorhynchus kisutch) on the nutritional value retention during frozen storage

A commercial diet enriched with synthetic antioxidants (butylated-hydroxytoluene and ethoxyquin (diet I) was fed to coho salmon (Oncorhynchus kisutch) and its effects were compared to two diets enriched with natural antioxidants, tocopherol-rich mixture (diet II), tocopherol-rosemary extract mixture (diet III). Once sacrificed, individual fishes were kept frozen at $-18^{\circ} \mathrm{C}$ for up to 18 months and then analyses were carried out on the frozen salmon muscle. The feeding of diet II led to frozen samples showing higher contents of sarcoplasmic proteins and $\gamma$ - and $\delta$-tocopherols when compared to their counterparts previously fed with diet I. No effect of dietary antioxidant profile could be detected on proximate composition, $\alpha$-tocopherol and astaxanthin contents or color $\left(L^{*}, a^{*}, b^{*}\right)$ parameters. Concerning the fatty acid composition, the fish samples corresponding to diet II showed higher $\mathrm{C} 22: 6 \omega 3$ and monounsaturated contents, but lower C20:5 13 and saturated contents when compared to their counterparts from diet I.

KEY-WORDS: Antioxidants - Diet - Fatty acids - Frozen storage - Oncorhynchus kisutch - Proximate composition.

\section{INTRODUCTION}

Marine foods have recently attracted a great interest from consumers as sources of nutritional components that have positive benefits for human health (Simopoulos, 1997). The lipid fraction is now the subject of a great deal of attention because of its high content of $\omega 3$ polyunsaturated fatty acids; among them, eicosapentaenoic acid (EPA, $\mathrm{C} 20: 5 \omega 3)$ has been related to cardiovascular health protection, while docosahexaenoic acid (DHA, $\mathrm{C} 22: 6 \omega 3)$ has been associated with the prevention of neurological disorders (Knoch et al., 2009, Valenzuela, 2009).

The unusual rapid rate of deterioration of seafood quality has been recognized for many years. Thus, freezing and frozen storage have largely been employed to retain sensory quality and nutrients. However, frozen marine species with both highly unsaturated lipid composition and pro-oxidant compounds have shown to suffer from enzymatic and non-enzymatic rancidity development (Erickson, 1997, Aubourg et al., 1999), leading to protein denaturation (Mackie, 1993) and loss in nutrients (Castrillón et al., 1996).

To extend the shelf life of frozen fatty fish species, many efforts have been directed to the employment of antioxidants. Since synthetic antioxidants have been reported to behave as carcinogen and mutating agents, more attention has been addressed to natural antioxidant addition. Accordingly, recent research has been focused on the employment of endogenous-type antioxidants (namely, tocopherols and organic acids) (Aubourg et al., 2004, Medina et al., 2009, Taheri et al., 2012) or natural antioxidants present in plant extracts (namely, polyphenol compounds) (Stodolnik et al., 2005, Lugasi et al., 2007, Tironi et al., 2010). 
Where aquaculture development is concerned, great attention has also been paid to the antioxidants present in cultivated fish feeds. Consequently, fish farmers have included a wide range of permitted synthetic (He and Ackman, 2000; Lundebye et al., 2010) and natural (Stéphan et al., 1995, Waagbø et al., 1993, Hamre et al., 1998) antioxidants in order to enhance the lipid stability of the corresponding processed food.

The present work focuses on the nutritional value of frozen farmed coho salmon (Oncorhynchus kisutch). A commercial diet enriched with butylatedhydroxytoluene (BHT) and ethoxyquin (EQ) (diet I) was fed to salmon fish and compared to two other diets, one of them including a tocopherolrich mixture (diet II) and the other, a tocopherolrosemary extract mixture (diet III). The basic aim of the study was to investigate the potential benefits of the natural antioxidants present in the diet for the nutritional value of the frozen product.

\section{MATERIALS AND METHODS}

\subsection{Salmon diets provided}

The coho salmon individuals used in this study were cultivated in three different tanks by EWOS Innovation Research (Colaco, Puerto Montt, Chile) under the same experimental conditions reported by Ortiz et al. (2009). Thus, a diet with the following proximate composition was employed in all tanks: protein $(43.0 \%)$, fat $(29.0 \%)$, moisture $(7.0 \%)$, ash $(6.5 \%)$, crude fiber $(1.3 \%)$ and carbohydrates $(13.2 \%)$; the distribution of the fat composition in the diet into saturated (SFA), monounsaturated (MUFA) and polyunsaturated (PUFA) fatty acid groups was in all cases $32.5 \%, 27.0 \%$ and $40.2 \%$, respectively.

In accordance with the objectives of this work, each of the three tanks was fed with a different antioxidant composition. Thus, the first tank was fed with an antioxidant mixture including 19.3, 3.0 and $22.4 \mathrm{mg}$ of $\mathrm{EQ}, \mathrm{BHT}$ and total tocopherols, respectively, per $\mathrm{kg}$ of feed (diet I); the antioxidant mixture provided to the second tank included 2.9, 0.0 and $101 \mathrm{mg}$ of EQ, BHT and total tocopherols, respectively, per $\mathrm{kg}$ of feed (diet II); and the third tank was fed with an antioxidant mixture including 2.3, 0.0, 45, 18 and $13 \mathrm{mg}$ of $\mathrm{EQ}, \mathrm{BHT}$, total tocopherols, carnosic acid and carnosol, respectively, per $\mathrm{kg}$ of feed (diet III).

\subsection{Raw material, processing and sampling}

Once the individual coho salmons had reached ca. $2500 \mathrm{~g}$ weight, 30 fish per tank were withdrawn, sacrificed by a sharp blow to the head, the gills cut and bled in a water-ice mixture, beheaded, gutted and kept in ice for $24 \mathrm{~h}$ until they arrived at our laboratory. The fish were then frozen at $-40^{\circ} \mathrm{C}$ in individual low-density polyethylene bags, with hermetic sealing. After 3 days, the fish were stored at $-18^{\circ} \mathrm{C}$ in a freezing room. The frozen fish were taken for analysis on months $0,3,6,9,12$ and 18 of storage at $-18^{\circ} \mathrm{C}$. From each tank under study, five different individual fish were independently analyzed at each sampling time to achieve the statistical analysis $(n=5)$. Analyses were carried out on the white muscle included in the region from the end of the dorsal fin backwards towards the anus.

\subsection{Proximate composition assessment}

Moisture content was determined from the difference between the weight of fresh homogenized muscle (1-2 g) and the weight recorded after 16-18 hr at $100-102^{\circ} \mathrm{C}$, according to the AOAC (1990) method. Results were calculated as $\mathrm{g}_{100 \mathrm{~g}^{-1} \text { muscle. }}$

Protein content was measured by the Kjeldahl method (AOAC, 1990), employing the 6.25 conversion

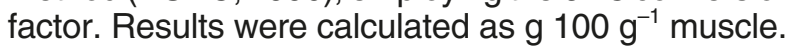

The lipid fraction was extracted by the Bligh and Dyer (1959) method, by employing a single-phase solubilization of the lipids using a chloroformmethanol (1:1) mixture. Quantification results were expressed as $\mathrm{g}$ lipid $100 \mathrm{~g}^{-1}$ muscle.

Ash content was measured according to the AOAC (1990) method by heating at $550^{\circ} \mathrm{C}$. Results

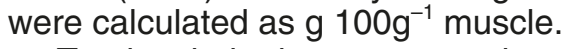

Total carbohydrates were estimated by rounding up, with the results expressed as $\mathrm{g} 100 \mathrm{~g}^{-1}$ muscle.

Sarcoplasmic protein extracts were prepared in a low-ionic strength extraction buffer and quantified according to Piñeiro et al. (1999). Results were expressed as g $100 \mathrm{~g}^{-1}$ muscle.

\subsection{Antioxidant content assessment}

$\mathrm{EQ}$ was determined according to the $\mathrm{He}$ and Ackman (2000) method with direct extraction from salmon muscle with acetonitrile followed by HPLC separation using a reversed-phase C18 column. Quantification by fluorescence detection was achieved by means of an external standard curve. Results were calculated as $\mathrm{mg} \mathrm{EQ} \mathrm{Kg}^{-1}$ muscle.

BHT was determined according to the method described by Lundebye et al. (2010). Extraction from the muscle was carried out using acetonitrile followed by HPLC separation with fluorescence detection. Quantification was achieved by means of an external standard curve. Results were calculated as $\mathrm{mg} \mathrm{BHT} \mathrm{kg}^{-1}$ muscle.

Tocopherols were determined in the lipid extracts of the salmon muscle by HPLC analysis with fluorescence detection, following the standard method Ce 8-89 (AOCS, 1993). Tocopherols were identified and quantified using the external standards of the different molecules tested $(\alpha-, \beta-$, $\gamma$-, and $\delta$-tocopherol) (Merck, Darmstadt, Germany). Results were calculated as $\mathrm{mg}$ tocopherols $\mathrm{kg}^{-1}$ muscle.

Astaxanthin (AX) content was measured according to the Sheehan et al. (1998) method. Fish muscle was extracted from the salmon with acetone, 
and the extract was dried under nitrogen flux and dissolved in the mobile phase (20\% ethyl acetate and $80 \%$ methanol/water, 9/1). The absence of 9Z- and 13Z-isomers was confirmed. Results were calculated as mg all-E-AX $\mathrm{kg}^{-1}$ muscle.

\subsection{Fatty acid composition analysis}

Lipid extracts were converted into fatty acid methyl esters (FAME) using acetyl chloride and analyzed by gas liquid chromatography (Perkin-Elmer 8700 chromatograph), employing a fused silica capillary column SP-2330 $(0.25 \mathrm{~mm}$ i.d. $\times 30 \mathrm{~m}$, Supelco Inc., Bellefonte, PA, USA) (Aubourg et al., 1995). The temperature program was as follows: increased from 145 to $190^{\circ} \mathrm{C}$ at $1.0^{\circ} \mathrm{C} \mathrm{min} \mathrm{m}^{-1}$ and from $190^{\circ} \mathrm{C}$ to $210^{\circ} \mathrm{C}$ at $5.0^{\circ} \mathrm{C} \mathrm{min}^{-1}$; held for $13.5 \mathrm{~min}$ at $210^{\circ} \mathrm{C}$. The carrier gas was nitrogen at 10 psi and detection was performed with a flame ionization detector (FID) at $250^{\circ} \mathrm{C}$. A programmed temperature vaporizer injector was employed in the split mode $(150: 1)$ and was heated from 45 to $275^{\circ} \mathrm{C}$ at $15^{\circ} \mathrm{C} \mathrm{min}^{-1}$. Peaks corresponding to FAME were identified by comparing their retention times with those of standard mixtures (Qualmix Fish, Larodan, Malmo, Sweden; FAME Mix, Supelco, Inc.). Peaks were automatically integrated; C19:0 fatty acid was used as internal standard for quantitative purposes. The content of each fatty acid was expressed as $\mathrm{g} 100 \mathrm{~g}^{-1}$ total fatty acids.

\subsection{Instrumental color analysis}

A color analysis (CIE $1976 \mathrm{~L}^{*}, \mathrm{a}^{*}, \mathrm{~b}^{*}$ ) was performed by employing a tristimulus colorimeter (Hunter Labscan 2.0/45) (Ortiz et al., 2008). Measurements were made directly on the salmon muscle by employing a quartz cuvette. For each sample analysis, color scores were obtained as mean values of four measurements obtained by rotating the measuring head $90^{\circ}$ between duplicate measurements per position.

\subsection{Statistical analysis}

The data obtained were subjected to the ANOVA method $(p<0.05)$ to explore differences in two different ways: diet effect and effect of frozen storage time. Comparison of means was performed using a least-squares difference (LSD) method. Statistica software (Statsoft Inc., Tulsa, OK, USA; version $6.0,2001$ ) was employed.

\section{RESULTS AND DISCUSSION}

\subsection{Proximate composition}

Table 1 indicates the results obtained for the proximate composition of frozen salmon muscle. The data are shown as value ranges since none of the chemical constituents provided a definite tendency (increasing or decreasing scores) throughout the frozen storage period. Additionally, no differences $(p>0.05)$ could be assessed among fish individuals corresponding to the three different diets previously provided.

Proximate composition profile obtained agreemeent with the previous research carried out on farmed coho salmon individuals (Perea et al., 2008; Vinagre et al., 2011). The present results were, however, different from those obtained for the same species under wild condition; thus, wild individuals showed higher moisture contents and lower lipid values, while protein and ash contents remained quite constant (Vinagre et al., 2011).

The analysis of the sarcoplasmic protein fraction showed some differences related to the previous feeding (Table 2). Thus, individuals corresponding to diet II provided higher mean values than their counterparts from diet I; such differences were significant at months 6,12 and 18. An increase in the protective action on sarcoplasmic protein fraction can be concluded as a consequence of employing the tocopherol-rich diet under the present conditions. Additionally, a marked sarcoplasmic protein content decrease was obtained for all kinds of samples as a result of the storage time.

Protein damage during the frozen storage of fish has partly been attributed to interaction with the oxidized lipids produced throughout frozen storage (Mackie, 1993; Castrillón et al., 1996). In a parallel study to the present one (Ortiz et al., 2009), individuals corresponding to diet II showed a higher

Table 1

Proximate composition (g $100 \mathrm{~g}^{-1}$ muscle) ${ }^{\star}$ of frozen coho salmon previously fed with different diets ${ }^{\star \star}$

\begin{tabular}{cccc}
\hline Constituent & Diet I & Diet II & Diet III \\
\hline Moisture & $59.2-69.4$ & $58.0-65.8$ & $58.1-67.3$ \\
Proteins & $19.0-24.8$ & $19.1-24.2$ & $18.8-22.4$ \\
Lipids & $9.1-14.4$ & $11.6-16.0$ & $10.7-17.3$ \\
Ash & $1.2-1.3$ & 1.3 & 1.3 \\
Carbohydrates & $0.6-1.3$ & $1.0-1.6$ & $1.1-1.8$ \\
\hline
\end{tabular}

* Value ranges obtained throughout the frozen storage. Values were obtained from five $(n=5)$ replicates at each sampling time in fish corresponding to each diet.

** Diet composition as expressed in the Materials and Methods section. 
Table 2

Sarcoplasmic protein (g $100 \mathrm{~g}^{-1}$ muscle) ${ }^{\star}$ and tocopherol (mg kg-1 muscle)* contents in frozen coho salmon previously fed with different diets**

\begin{tabular}{|c|c|c|c|c|c|c|c|}
\hline \multirow{2}{*}{ Parameter } & \multirow{2}{*}{ Diet } & \multicolumn{6}{|c|}{ Frozen storage time (months) } \\
\hline & & 0 & 3 & 6 & 9 & 12 & 18 \\
\hline \multirow[t]{3}{*}{$\begin{array}{l}\text { Sarcoplasmic } \\
\text { proteins }\end{array}$} & 1 & $\begin{array}{l}\text { c } 4.7 \\
(0.4)\end{array}$ & $\begin{array}{l}\text { c } 4.1 \\
(0.4)\end{array}$ & $\begin{array}{c}a b 2.8 z \\
(0.3)\end{array}$ & $\begin{array}{c}\text { a } 2.5 \mathrm{z} \\
(0.3)\end{array}$ & $\begin{array}{l}\text { b } 3.2 \\
(0.2)\end{array}$ & $\begin{array}{c}\text { a } 2.3 \mathrm{z} \\
(0.5)\end{array}$ \\
\hline & II & $\begin{array}{l}\text { c } 5.2 \\
(0.5)\end{array}$ & $\begin{array}{c}\text { bc } 4.5 \\
(0.2)\end{array}$ & $\begin{array}{c}a b 3.8 y \\
(0.5)\end{array}$ & $\begin{array}{c}a b 3.9 y \\
(0.6)\end{array}$ & $\begin{array}{l}\text { a } 3.3 \\
(0.3)\end{array}$ & $\begin{array}{c}\text { a } 3.4 \text { y } \\
(0.4)\end{array}$ \\
\hline & III & $\begin{array}{l}\text { b } 5.0 \\
(0.2)\end{array}$ & $\begin{array}{l}\text { b } 4.8 \\
(0.3)\end{array}$ & $\begin{array}{c}\text { a } 3.2 \text { zy } \\
(0.3)\end{array}$ & $\begin{array}{c}\text { a } 3.4 \text { zy } \\
(0.9)\end{array}$ & $\begin{array}{l}\text { a } 3.3 \\
(0.4)\end{array}$ & $\begin{array}{c}\text { a } 3.0 \text { zy } \\
(0.5)\end{array}$ \\
\hline \multirow[t]{3}{*}{$\alpha$-tocopherol } & I & $\begin{array}{c}\text { b } 209.3 \\
(55.9)\end{array}$ & $\begin{array}{c}\text { b } 264.5 \\
(75.3)\end{array}$ & $\begin{array}{c}\text { ab } 197.4 \\
(79.0)\end{array}$ & $\begin{array}{c}\text { ab } 167.4 \\
(57.8)\end{array}$ & $\begin{array}{c}a b 133.9 \\
(20.6)\end{array}$ & $\begin{array}{l}\text { a } 98.0 \\
(20.7)\end{array}$ \\
\hline & II & $\begin{array}{c}\text { bc } 212.5 \\
(37.6)\end{array}$ & $\begin{array}{c}\text { c } 266.4 \\
(38.0)\end{array}$ & $\begin{array}{c}\text { ab } 128.3 \\
(74.4)\end{array}$ & $\begin{array}{c}\text { ab } 159.6 \\
(44.0)\end{array}$ & $\begin{array}{c}a b 155.3 \\
(37.5)\end{array}$ & $\begin{array}{c}\text { a } 136.1 \\
(32.1)\end{array}$ \\
\hline & III & $\begin{array}{c}\text { cd } 246.8 \\
(57.0)\end{array}$ & $\begin{array}{c}\text { d } 336.7 \\
(36.0)\end{array}$ & $\begin{array}{c}\text { bc } 173.3 \\
(39.8)\end{array}$ & $\begin{array}{c}a b 133.7 \\
(52.4)\end{array}$ & $\begin{array}{c}a b 129.8 \\
(33.3)\end{array}$ & $\begin{array}{c}\text { a } 106.5 \\
(18.6)\end{array}$ \\
\hline \multirow[t]{3}{*}{$\gamma$-tocopherol } & I & $\begin{array}{c}\text { bc } 7.3 \mathrm{z} \\
(2.0)\end{array}$ & $\begin{array}{c}\text { c } 10.1 \mathrm{z} \\
(6.2)\end{array}$ & $\begin{array}{c}\text { c } 13.1 \\
(7.4)\end{array}$ & $\begin{array}{c}\text { c } 14.0 \\
(5.2)\end{array}$ & $\begin{array}{c}a b 4.6 z \\
(1.4)\end{array}$ & $\begin{array}{c}\text { a } 2.6 z \\
(1.2)\end{array}$ \\
\hline & II & $\begin{array}{c}a b 23.9 y \\
(7.2)\end{array}$ & $\begin{array}{c}\text { b } 30.8 \text { y } \\
(3.6)\end{array}$ & $\begin{array}{c}\text { ab } 20.7 \\
(5.7)\end{array}$ & $\begin{array}{c}\text { ab } 21.8 \\
(11.3)\end{array}$ & $\begin{array}{c}a b 20.3 y \\
(6.0)\end{array}$ & $\begin{array}{c}\text { a } 14.7 y \\
(3.8)\end{array}$ \\
\hline & III & $\begin{array}{c}19.6 \mathrm{y} \\
(9.8)\end{array}$ & $\begin{array}{c}25.5 y \\
(8.7)\end{array}$ & $\begin{array}{l}14.3 \\
(3.8)\end{array}$ & $\begin{array}{c}14.3 \\
(10.6)\end{array}$ & $\begin{array}{c}13.4 \mathrm{y} \\
(7.2)\end{array}$ & $\begin{array}{c}10.8 y \\
(2.4)\end{array}$ \\
\hline \multirow[t]{3}{*}{$\delta$-tocopherol } & I & $\begin{array}{l}1.9 z \\
(0.4)\end{array}$ & $\begin{array}{l}1.1 \mathrm{z} \\
(1.1)\end{array}$ & $\begin{array}{c}1.9 \\
(1.1)\end{array}$ & $\begin{array}{l}1.8 z \\
(1.4)\end{array}$ & $\begin{array}{l}1.4 \mathrm{z} \\
(1.1)\end{array}$ & $\begin{array}{l}1.1 z \\
(0.6)\end{array}$ \\
\hline & II & $\begin{array}{c}a b 3.1 y \\
(0.7)\end{array}$ & $\begin{array}{c}a b c 4.0 y \\
(1.7)\end{array}$ & $\begin{array}{l}\text { a } 2.1 \\
(0.9)\end{array}$ & $\begin{array}{c}\text { c } 5.3 \text { y } \\
(1.3)\end{array}$ & $\begin{array}{c}c 5.6 y \\
(1.7)\end{array}$ & $\begin{array}{c}\text { bc } 4.5 y \\
(1.0)\end{array}$ \\
\hline & III & $\begin{array}{c}\text { a } 1.1 \mathrm{z} \\
(0.6)\end{array}$ & $\begin{array}{c}\text { b } 3.7 \text { zy } \\
(1.5)\end{array}$ & $\begin{array}{c}\text { ab } 1.9 \\
(1.7)\end{array}$ & $\begin{array}{c}\text { a } 0.9 \mathrm{z} \\
(0.7)\end{array}$ & $\begin{array}{c}\text { a } 0.5 \mathrm{z} \\
(0.4)\end{array}$ & $\begin{array}{c}\text { a } 0.5 \mathrm{z} \\
(0.3)\end{array}$ \\
\hline
\end{tabular}

* Mean values of five $(n=5)$ replicates; standard deviations are indicated in brackets. For each parameter and for each frozen time, values followed by different letters $(z, y)$ express significant $(p<0.05)$ differences as a result of the diet employed. For each parameter and for each diet, values preceded by different letters $(a, b, c)$ express significant $(p<0.05)$ differences as a result of the frozen time. No letters are indicated in the case of no significant differences $(p>0.05)$.

** Diet compositions as expressed in the Materials and Methods section.

rancidity stability and lower oxidized taste scores than their counterparts previously fed with the diet including a rich mixture of synthetic antioxidants. The present results concerning a higher retention of sarcoplasmic protein content in individuals corresponding to diet II could be explained on the basis of this lower oxidation development.

\subsection{Presence of synthetic antioxidants}

Synthetic antioxidants (BHT and EQ) content was analyzed in salmon muscle throughout the frozen storage. In the case of BHT, this compound could not be quantified satisfactorily since values ranged below $0.01 \mathrm{mg} \mathrm{kg}^{-1}$ muscle in all cases. Previous research has shown that BHT provided in the diet would be highly retained in the fish liver (Hollas et al., 2008). A study concerning the synthetic antioxidant contents in cultured fish in Taiwan showed that a negligible content was present in the fish muscle, while fish liver accounted for a 0-12.3 ppm range (Hwang et al., 1995). A negligible amount was also obtained in farmed cod fed with a diet including such synthetic antioxidant (Lundebye et al., 2010); however in the same experiment, BHT was detected in Atlantic salmon (Salmo salar), rainbow trout (Oncorhynchus mykiss) and halibut (Hippoglossus hippoglossus) in the range of $1.7-3.9 \mathrm{mg} \mathrm{kg}^{-1}$ muscle.

Concerning $E Q$, a trace presence was obtained in most samples in this study, with all values ranging below $0.03 \mathrm{mg} \mathrm{kg}^{-1}$ muscle. A higher content in individuals corresponding to diet I was not attained, while no differences could be depicted with frozen storage time $(p>0.05)$. Previous research has investigated the biological fate of EQ in salmonid species (He and Ackman, 2000; Lundebye et al., 2010). Both studies revealed that $E Q$ could be converted into de-ethylated EQ (hydroxy-trimethyl-dihydroquinoline) and oxidized metabolites (dihydro-trimethyl-quinolone and dihydroethoxy-trimethylquinoline), so that low values of $E Q$ were obtained in the final product. 


\subsection{Tocopherol presence}

The Tocopherol analysis is included in Table 2. The presence of $\beta$-tocopherol was found to be negligible in most cases, according to its previously reported low deposition ability (Sigurgisladóttir et al., 1994).

The analysis of $\alpha$-tocopherol content indicated that no significant differences could be attributed to the diet applied when comparing the different kinds of frozen samples. However, a general $\alpha$-tocopherol loss tendency was observed as a result of the frozen storage time; this decrease was found significant at the end of the experiment in all cases. Previous research also accounts for $\alpha$-tocopherol content losses in frozen fish muscle such as Atlantic salmon (S. salar) (Hamre et al., 1998), rainbow trout (O. mykiss), horse mackerel (Trachurus trachurus) (Medina et al., 2009) and channel catfish (Ictalurus punctatus) (Brannan and Erickson, 1996); these losses were attributed to $\alpha$-tocopherol consumption in order to retard lipid oxidation in fish muscle throughout the frozen storage.

Concerning the $\gamma$-tocopherol presence, lower mean values were observed in individuals corresponding to diet I when compared to their counterparts from diets enriched with natural antioxidants; differences were found significant at months $0,3,12$ and 18 . A higher retention of this tocopherol molecule is concluded to be produced in individuals belonging to both diets including relatively high levels of natural antioxidants. Additionally, higher mean values were also obtained for samples corresponding to diet II when compared to their counterparts from diet III; however, differences were not found to be significant. Concerning the effect of the frozen storage time, a mean value analysis leads to a general $\gamma$-tocopherol content decrease; this decrease was found significant in individuals corresponding to diet I at the end of the experiment. Such results agree with a previous investigation on frozen channel catfish (I. punctatus) (Brannan and Erickson, 1996) fillets. On the contrary, no loss in $\gamma$-tocopherol content during the frozen storage of Atlantic salmon ( $S$. salar) was observed (Hamre et al., 1998).

The content of $\delta$-tocopherol showed higher mean values throughout the whole experiment in individuals corresponding to diet II; differences were found significant at months $0,9,12$ and 18. Consequently, a marked effect of dietary antioxidants on the content of this tocopherol compound is inferred. Large fish-to-fish differences were found in most cases, so that a definite tendency of $\delta$-tocopherol content throughout the frozen storage time was not attained for any kind of sample under study. In agreement with the present results, previous research did not lead to content losses for this tocopherol molecule during the frozen storage of Atlantic salmon ( $S$. salar) (Hamre et al., 1998).

Tocopherols are known as endogenous antioxidants that can act as scavengers of free radicals, so that protection against the very early stages of lipid oxidation would be favored (Jensen et al., 1998). Higher values of $\gamma$ - and $\delta$-tocopherol found in individuals corresponding to diet II can be explained as being influenced by the antioxidant composition of the diet provided; these higher values would be in agreement with the lower oxidation development found in such individuals in the above-mentioned parallel experiment (Ortiz et al., 2009).

\subsection{Astaxanthin content and color changes}

Color plays an important role in the appearance, presentation and acceptability of seafoods, especially in those related to salmonid species (Benzce Rørå et al., 2005; Choubert and Baccaunaud, 2006). $A X$ is well known as the main pigment responsible for the pink color of salmonid fish species, so its retention during processing should be very important to guarantee consumer acceptance and retain the commercial value of the product.

AX content values were included in the $6-12 \mathrm{mg}$ $\mathrm{kg}^{-1}$ muscle range (Table 3 ). Differences among individuals corresponding to the various diets could hardly be found, so that a definite effect of the diet on the $A X$ content could not be inferred. In a previous study (Jensen et al., 1998), the addition of $\alpha$-tocopherol in the diet did not affect the AX retention in rainbow trout (O. mykiss) muscle either. In addition, a definite tendency with frozen storage time could not be concluded in the actual research for the $A X$ content in the different kinds of samples. Under the present experimental conditions, it can be concluded that diets enriched with synthetic antioxidants as well as those enriched with natural ones have led to an AX content retention in the frozen salmon muscle. This $A X$ content retention agrees with previous investigation concerning the same species under similar frozen conditions, previously fed with a diet enriched with synthetic antioxidants (Vinagre et al., 2011). However, and contrary to the present results, an AX content decrease during frozen storage has been described for Atlantic salmon ( $S$. salar) (Christophersen et al., 1992) and rainbow trout (O. mykiss) (Jensen et al., 1998).

Color changes in salmon muscle were investigated by means of physical (CIE L*, $a^{*}$ and $b^{\star}$ ) analysis. According to Table 3 , no significant differences could be observed among samples, so that no effect of dietary antioxidants provided to salmon could be concluded on any of the color parameters under study. This result agrees with the fact that $A X$ content did not show practically any differences as a result of the antioxidants provided in the diet.

In the case of the $L^{*}$ value, an increasing tendency with frozen time could be concluded for all kinds of samples. A marked increase in this parameter has already been mentioned as a result of different technological treatments on salmonid species such as frozen storage (Christophersen et al., 1992), vacuum-packaging refrigerated $\left(4^{\circ} \mathrm{C}\right)$ storage (Choubert and Baccaunaud, 2006) and hydrostatic high-pressure (Amanatidou et al., 2000). 
Table 3

Astaxanthin content ( $\mathrm{mg} \mathrm{kg}^{-1}$ muscle) and color $\left(\mathrm{L}^{\star}, \mathrm{a}^{\star}\right.$ and $\mathrm{b}^{\star}$ values) assessment ${ }^{\S}$ in frozen coho salmon previously fed with different diets ${ }^{\S \S}$

\begin{tabular}{|c|c|c|c|c|c|c|c|}
\hline \multirow{2}{*}{ Parameter } & \multirow{2}{*}{ Diet } & \multicolumn{6}{|c|}{ Frozen storage time (months) } \\
\hline & & 0 & 3 & 6 & 9 & 12 & 18 \\
\hline \multirow[t]{3}{*}{ Astaxanthin } & I & $\begin{array}{c}\text { ab } 8.4 \\
(1.8)\end{array}$ & $\begin{array}{c}\text { a } 6.2 \text { z } \\
(1.1)\end{array}$ & $\begin{array}{c}\text { b } 10.3 \\
(1.3)\end{array}$ & $\begin{array}{c}a b 8.7 \\
(1.3)\end{array}$ & $\begin{array}{c}\text { b } 10.7 \\
(1.8)\end{array}$ & $\begin{array}{c}\text { b } 10.6 \\
(0.6)\end{array}$ \\
\hline & II & $\begin{array}{c}a b 8.0 \\
(1.5)\end{array}$ & $\begin{array}{c}\text { a } 7.8 \text { zy } \\
(1.1)\end{array}$ & $\begin{array}{c}a b 10.0 \\
(0.8)\end{array}$ & $\begin{array}{l}\text { a } 7.9 \\
(1.6)\end{array}$ & $\begin{array}{c}\text { b } 12.0 \\
(1.3)\end{array}$ & $\begin{array}{c}a b 9.8 \\
(0.9)\end{array}$ \\
\hline & III & $\begin{array}{c}a b 8.5 \\
(1.2)\end{array}$ & $\begin{array}{c}\text { a } 8.9 \text { y } \\
(1.3)\end{array}$ & $\begin{array}{c}\mathrm{ab} 9.1 \\
(1.1)\end{array}$ & $\begin{array}{l}\text { a } 7.4 \\
(0.9)\end{array}$ & $\begin{array}{c}\text { b } 10.1 \\
(1.4)\end{array}$ & $\begin{array}{l}\text { b } 11.0 \\
(1.15)\end{array}$ \\
\hline \multirow[t]{3}{*}{$L^{*}$ value } & I & $\begin{array}{c}\text { a } 46.9 \\
(2.0)\end{array}$ & $\begin{array}{c}\text { b } 50.6 \\
(0.8)\end{array}$ & $\begin{array}{c}\text { b } 51.1 \\
(1.1)\end{array}$ & $\begin{array}{c}\text { b } 51.4 \\
(1.9)\end{array}$ & $\begin{array}{c}\text { b } 51.3 \\
(0.9)\end{array}$ & $\begin{array}{c}\text { b } 51.4 \\
(0.9)\end{array}$ \\
\hline & II & $\begin{array}{c}\text { a } 48.3 \\
(1.7)\end{array}$ & $\begin{array}{c}\text { ab } 50.5 \\
(2.0)\end{array}$ & $\begin{array}{c}\text { b } 53.5 \\
(0.9)\end{array}$ & $\begin{array}{l}\text { b } 51.9 \\
(1.2)\end{array}$ & $\begin{array}{c}\text { b } 51.9 \\
(1.0)\end{array}$ & $\begin{array}{c}\text { b } 50.9 \\
(0.3)\end{array}$ \\
\hline & III & $\begin{array}{c}\text { a } 48.7 \\
(1.9)\end{array}$ & $\begin{array}{c}a b 50.6 \\
(0.8)\end{array}$ & $\begin{array}{c}a b 50.5 \\
(2.0)\end{array}$ & $\begin{array}{c}\text { a } 47.1 \\
(1.9)\end{array}$ & $\begin{array}{c}\text { bc } 51.8 \\
(1.1)\end{array}$ & $\begin{array}{c}\text { c } 53.3 \\
(0.9)\end{array}$ \\
\hline \multirow[t]{3}{*}{$a^{*}$ value } & I & $\begin{array}{c}\text { ab } 34.7 \\
(1.2)\end{array}$ & $\begin{array}{c}\text { c } 36.9 \\
(0.8)\end{array}$ & $\begin{array}{c}\text { c } 36.9 \\
(0.6)\end{array}$ & $\begin{array}{c}\text { c } 37.2 \\
(1.0)\end{array}$ & $\begin{array}{c}\text { abc } 34.6 \\
(1.7)\end{array}$ & $\begin{array}{c}\text { a } 33.9 \\
(1.7)\end{array}$ \\
\hline & II & $\begin{array}{c}a b 35.8 \\
(2.3)\end{array}$ & $\begin{array}{c}a b 36.5 \\
(1.5)\end{array}$ & $\begin{array}{c}\text { a } 35.6 \\
(0.9)\end{array}$ & $\begin{array}{c}\text { b } 37.3 \\
(0.4)\end{array}$ & $\begin{array}{c}\text { a } 35.7 \\
(1.1)\end{array}$ & $\begin{array}{c}\text { a } 35.6 \\
(0.7)\end{array}$ \\
\hline & III & $\begin{array}{c}\text { ab } 36.2 \\
(1.0)\end{array}$ & $\begin{array}{c}\text { ab } 36.9 \\
(0.8)\end{array}$ & $\begin{array}{c}\text { ab } 36.5 \\
(1.5)\end{array}$ & $\begin{array}{c}\text { b } 38.1 \\
(0.8)\end{array}$ & $\begin{array}{c}\text { ab } 36.9 \\
(0.6)\end{array}$ & $\begin{array}{c}\text { a } 35.4 \\
(0.9)\end{array}$ \\
\hline \multirow[t]{3}{*}{$b^{*}$ value } & I & $\begin{array}{c}\text { b } 36.1 \\
(0.5)\end{array}$ & $\begin{array}{c}\text { ab } 35.1 \\
(1.3)\end{array}$ & $\begin{array}{c}a b 34.7 \\
(0.7)\end{array}$ & $\begin{array}{c}a b 36.1 \\
(1.4)\end{array}$ & $\begin{array}{c}\text { a } 33.9 \\
(1.2)\end{array}$ & $\begin{array}{c}\text { ab } 33.9 \\
(1.7)\end{array}$ \\
\hline & II & $\begin{array}{c}\text { bc } 35.6 \\
(1.5)\end{array}$ & $\begin{array}{c}\text { c } 36.3 \\
(1.2)\end{array}$ & $\begin{array}{c}\text { a } 33.0 \\
(0.6)\end{array}$ & $\begin{array}{c}\text { abc } 34.9 \\
(1.9)\end{array}$ & $\begin{array}{c}\text { bc } 35.3 \\
(1.1)\end{array}$ & $\begin{array}{c}\text { ab } 33.7 \\
(0.7)\end{array}$ \\
\hline & III & $\begin{array}{c}a b 35.6 \\
(1.6)\end{array}$ & $\begin{array}{c}\text { b } 36.3 \\
(1.4)\end{array}$ & $\begin{array}{c}\text { a } 33.0 \\
(1.2)\end{array}$ & $\begin{array}{c}a b 34.9 \\
(1.0)\end{array}$ & $\begin{array}{c}\text { b } 35.4 \\
(0.7)\end{array}$ & $\begin{array}{c}a b 34.7 \\
(0.9)\end{array}$ \\
\hline
\end{tabular}

However, $L^{*}$ values remained under 70 in all cases of the present study throughout the storage period, which has been depicted as the permitted border line value for salmonid species (Amanatidou et al., 2000).

Concerning $a^{*}$ and $b^{*}$ parameters, some differences with frozen storage time could be concluded for the three kinds of salmon samples. However, a definite tendency could not be inferred in any case. In all kinds of samples, $a^{*}$ value remained above 13 , which has been recognized as the permitted border line value for salmonid species (Amanatidou et al., 2000).

Previous investigations on fish species have proven a general $\mathrm{a}^{*}$ value decrease as a result of different technological treatments such as hydrostatic high-pressure (Ashie et al., 1996), frozen storage (Tironi et al., 2010) and vacuumpackaging (Gobantes et al., 1998). Concerning $b^{*}$ value, this parameter has been directly related to lipid oxidation development; thus, an important relationship between $b^{*}$ value and the formation of polymerized Schiff bases and fluorescent compounds has been proven (Undeland et al., 2003). As in the present research, previous studies did not find changes in $b^{*}$ value in salmonid species for the frozen storage (Tironi et al., 2010).

\subsection{Fatty acid analysis}

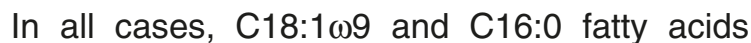
were found to be the most abundant, followed by $\mathrm{C} 22: 6 \omega 3, \mathrm{C} 16: 1 \omega 7$ and $\mathrm{C} 20: 5 \omega 3$. A similar profile was obtained by Perea et al., (2008) and reviewed by Vinagre et al., (2011) for the same farmed salmon species. Concerning EPA content (Table 4), a higher mean value was obtained in samples corresponding to diet I, being significantly higher at time 0 when compared to fish individuals corresponding to both diets enriched with natural antioxidants. The opposite result was obtained for DHA presence (Table 4); its mean value was in all cases lower in individuals corresponding to diet I, 
Table 4

Fatty acid analysis $\left(\mathrm{g} 100 \mathrm{~g}^{-1}\right.$ total fatty acids)* in frozen coho salmon previously fed with different diets ${ }^{\star *}$

\begin{tabular}{|c|c|c|c|c|c|c|c|}
\hline \multirow{2}{*}{ Parameter** } & \multirow{2}{*}{ Diet } & \multicolumn{6}{|c|}{ Frozen storage time (months) } \\
\hline & & 0 & 3 & 6 & 9 & 12 & 18 \\
\hline \multirow[t]{3}{*}{ EPA } & 1 & $\begin{array}{c}10.5 y \\
(1.8)\end{array}$ & $\begin{array}{l}10.3 \\
(2.1)\end{array}$ & $\begin{array}{l}10.2 \\
(1.8)\end{array}$ & $\begin{array}{c}10.4 \mathrm{y} \\
(1.8)\end{array}$ & $\begin{array}{c}8.8 \\
(1.4)\end{array}$ & $\begin{array}{l}9.0 \mathrm{y} \\
(1.8)\end{array}$ \\
\hline & II & $\begin{array}{l}6.4 \mathrm{z} \\
(1.6)\end{array}$ & $\begin{array}{c}6.7 \\
(1.4)\end{array}$ & $\begin{array}{c}6.7 \\
(2.1)\end{array}$ & $\begin{array}{l}6.4 \mathrm{z} \\
(1.7)\end{array}$ & $\begin{array}{c}6.1 \\
(1.4)\end{array}$ & $\begin{array}{c}5.7 \mathrm{zy} \\
(1.7)\end{array}$ \\
\hline & III & $\begin{array}{l}6.6 z \\
(1.5)\end{array}$ & $\begin{array}{c}6.5 \\
(1.8)\end{array}$ & $\begin{array}{c}6.8 \\
(2.3)\end{array}$ & $\begin{array}{c}7.0 \mathrm{zy} \\
(2.1)\end{array}$ & $\begin{array}{c}5.9 \\
(1.7)\end{array}$ & $\begin{array}{l}5.8 \mathrm{z} \\
(1.1)\end{array}$ \\
\hline \multirow[t]{3}{*}{$\mathrm{DHA}$} & I & $\begin{array}{c}22.2 \mathrm{z} \\
(1.8)\end{array}$ & $\begin{array}{c}22.1 \mathrm{z} \\
(1.3)\end{array}$ & $\begin{array}{c}21.7 \mathrm{z} \\
(1.1)\end{array}$ & $\begin{array}{l}21.9 \\
(2.1)\end{array}$ & $\begin{array}{l}23.2 \\
(1.1)\end{array}$ & $\begin{array}{l}22.2 \\
(1.2)\end{array}$ \\
\hline & II & $\begin{array}{c}26.2 y \\
(1.2)\end{array}$ & $\begin{array}{c}25.6 y \\
(1.9)\end{array}$ & $\begin{array}{c}25.6 y \\
(1.1)\end{array}$ & $\begin{array}{l}24.8 \\
(1.2)\end{array}$ & $\begin{array}{l}25.3 \\
(1.9)\end{array}$ & $\begin{array}{l}24.9 \\
(1.9)\end{array}$ \\
\hline & III & $\begin{array}{c}\text { ab } 23.8 z \\
(1.0)\end{array}$ & $\begin{array}{c}a b 22.8 \text { zy } \\
(1.3)\end{array}$ & $\begin{array}{c}\text { a } 21.9 \text { z } \\
(1.3)\end{array}$ & $\begin{array}{c}\text { ab } 23.2 \\
(1.5)\end{array}$ & $\begin{array}{c}\text { ab } 24.4 \\
(1.8)\end{array}$ & $\begin{array}{c}\text { b } 25.0 \\
(1.3)\end{array}$ \\
\hline \multirow[t]{3}{*}{$\begin{array}{l}\text { Total } \\
\text { SFA }\end{array}$} & I & $\begin{array}{l}24.5 \\
(1.3)\end{array}$ & $\begin{array}{l}25.3 \\
(1.1)\end{array}$ & $\begin{array}{l}25.0 \\
(1.2)\end{array}$ & $\begin{array}{l}24.4 \\
(1.2)\end{array}$ & $\begin{array}{c}26.4 \mathrm{y} \\
(1.3)\end{array}$ & $\begin{array}{c}26.6 y \\
(1.1)\end{array}$ \\
\hline & II & $\begin{array}{l}22.2 \\
(1.7)\end{array}$ & $\begin{array}{l}22.7 \\
(1.6)\end{array}$ & $\begin{array}{l}21.7 \\
(1.1)\end{array}$ & $\begin{array}{l}23.3 \\
(1.2)\end{array}$ & $\begin{array}{c}22.8 \mathrm{z} \\
(1.4)\end{array}$ & $\begin{array}{c}22.4 \mathrm{z} \\
(2.2)\end{array}$ \\
\hline & III & $\begin{array}{l}21.6 \\
(1.2)\end{array}$ & $\begin{array}{l}23.5 \\
(1.4)\end{array}$ & $\begin{array}{l}23.0 \\
(1.5)\end{array}$ & $\begin{array}{l}23.0 \\
(1.9)\end{array}$ & $\begin{array}{c}22.2 \mathrm{z} \\
(1.4)\end{array}$ & $\begin{array}{c}22.7 \mathrm{z} \\
(1.6)\end{array}$ \\
\hline \multirow[t]{3}{*}{ Total MUFA } & 1 & $\begin{array}{c}27.5 \mathrm{z} \\
(1.4)\end{array}$ & $\begin{array}{c}27.7 \mathrm{z} \\
(2.1)\end{array}$ & $\begin{array}{c}27.3 \mathrm{z} \\
(2.5)\end{array}$ & $\begin{array}{c}27.5 \mathrm{z} \\
(2.3)\end{array}$ & $\begin{array}{c}24.5 \mathrm{z} \\
(2.6)\end{array}$ & $\begin{array}{c}23.3 \mathrm{z} \\
(2.3)\end{array}$ \\
\hline & II & $\begin{array}{c}32.7 y \\
(1.2)\end{array}$ & $\begin{array}{c}31.3 \text { zy } \\
(1.8)\end{array}$ & $\begin{array}{c}31.2 \mathrm{zy} \\
(1.6)\end{array}$ & $\begin{array}{c}31.4 \text { zy } \\
(1.9)\end{array}$ & $\begin{array}{c}30.1 \mathrm{y} \\
(1.6)\end{array}$ & $\begin{array}{c}30.0 y \\
(2.7)\end{array}$ \\
\hline & III & $\begin{array}{c}a b 34.1 y \\
(2.3)\end{array}$ & $\begin{array}{c}\text { b } 34.2 \text { y } \\
(1.7)\end{array}$ & $\begin{array}{c}a b 34.0 y \\
(2.1)\end{array}$ & $\begin{array}{c}a b 31.9 y \\
(1.7)\end{array}$ & $\begin{array}{c}\text { a } 30.4 \text { y } \\
(1.5)\end{array}$ & $\begin{array}{c}a b 30.5 y \\
(2.0)\end{array}$ \\
\hline \multirow[t]{3}{*}{$\begin{array}{l}\text { Total } \\
\text { PUFA }\end{array}$} & 1 & $\begin{array}{l}48.0 \\
(2.1)\end{array}$ & $\begin{array}{c}47.0 y \\
(2.3)\end{array}$ & $\begin{array}{c}48.7 y \\
(1.6)\end{array}$ & $\begin{array}{l}48.1 \\
(1.9)\end{array}$ & $\begin{array}{l}49.1 \\
(1.6)\end{array}$ & $\begin{array}{l}50.1 \\
(2.3)\end{array}$ \\
\hline & II & $\begin{array}{l}45.1 \\
(2.8)\end{array}$ & $\begin{array}{c}46.0 \mathrm{zy} \\
(2.6)\end{array}$ & $\begin{array}{c}47.1 \text { zy } \\
(2.3)\end{array}$ & $\begin{array}{l}45.3 \\
(1.7)\end{array}$ & $\begin{array}{l}47.1 \\
(1.5)\end{array}$ & $\begin{array}{l}47.6 \\
(1.7)\end{array}$ \\
\hline & III & $\begin{array}{c}\mathrm{abc} 44.3 \\
(1.7)\end{array}$ & $\begin{array}{c}\text { a } 42.3 \text { z } \\
(1.8)\end{array}$ & $\begin{array}{c}a b 43.0 \mathrm{z} \\
(2.0)\end{array}$ & $\begin{array}{c}a b c 45.1 \\
(1.6)\end{array}$ & $\begin{array}{c}\text { c } 47.4 \\
(1.9)\end{array}$ & $\begin{array}{c}\text { c } 46.8 \\
(1.7)\end{array}$ \\
\hline \multirow[t]{3}{*}{$\omega 3 / \omega 6$ ratio } & 1 & $\begin{array}{c}5.2 \\
(0.8)\end{array}$ & $\begin{array}{c}5.2 \\
(0.9)\end{array}$ & $\begin{array}{c}5.2 \\
(1.2)\end{array}$ & $\begin{array}{c}5.4 \\
(1.4)\end{array}$ & $\begin{array}{c}6.4 \\
(1.3)\end{array}$ & $\begin{array}{c}5.3 \\
(0.6)\end{array}$ \\
\hline & II & $\begin{array}{c}5.4 \\
(0.9)\end{array}$ & $\begin{array}{c}4.8 \\
(0.7)\end{array}$ & $\begin{array}{c}5.6 \\
(1.6)\end{array}$ & $\begin{array}{c}5.3 \\
(0.8)\end{array}$ & $\begin{array}{c}6.1 \\
(0.9)\end{array}$ & $\begin{array}{c}5.2 \\
(1.1)\end{array}$ \\
\hline & III & $\begin{array}{c}4.5 \\
(1.2)\end{array}$ & $\begin{array}{c}4.7 \\
(1.1)\end{array}$ & $\begin{array}{c}4.8 \\
(1.0)\end{array}$ & $\begin{array}{c}4.9 \\
(0.9)\end{array}$ & $\begin{array}{c}5.1 \\
(1.3)\end{array}$ & $\begin{array}{c}5.2 \\
(1.1)\end{array}$ \\
\hline
\end{tabular}

* Mean values of five $(n=5)$ replicates; standard deviations are indicated in brackets. For each parameter and for each frozen time, values followed by different letters $(z, y)$ express significant $(p<0.05)$ differences as a result of the diet employed. For each parameter and for each diet, values preceded by different letters $(a, b, c)$ express significant $(p<0.05)$ differences as a result of the frozen time. No letters are indicated in the case of no significant differences $(p>0.05)$.

** Diet compositions as expressed in the Materials and Methods section. Abbreviations: EPA (eicosapentaenoic acid; C20:5 $\omega 3$ ), DHA (docosahexaenoic acid, C22:6 13 ), SFA (saturated fatty acids), MUFA (monounsaturated fatty acids) and PUFA (polyunsaturated fatty acids).

with scores significantly lower in the 0-6-month period when compared to individuals from diet II. In all cases, both fatty acids (EPA and DHA) hardly provided differences as a result of the frozen storage time in any of the different kinds of samples under study.
When the fatty acid groups are considered, the following general decreasing content sequence was obtained: PUFA > MUFA > SFA (Table 4). This similarity of fatty acid group composition among kinds of samples can be explained on the basis that the same fatty acid composition was present 
in the three diets. In this sense, previous research accounts for a marked effect of the fatty acid composition of the diet on the fatty acid composition of the product (Stéphan et al., 1995; Waagbø et al., 1993; Benzce Rørå et al., 2005). Additionally, dietary fish oils have shown an enhancement of the lipid oxidation development during frozen storage when compared to diets including non-marine oils (Stéphan et al., 1995; Waagbø et al., 1993); this result has been explained as a result of a higher PUFA presence in fish fed with marine oils.

According to Table 4, SFA analysis showed higher mean values for individuals corresponding to diet I; such differences were found significant at the 12-18-month period, while no differences were inferred between samples corresponding to both diets enriched with natural antioxidants. An opposite result could be concluded from the MUFA presence; thus, higher mean values were found in individuals corresponding to diets II and III, with such differences significant at months 0,12 and 18. Related to PUFA content, mean values were found higher throughout the whole experiment in individuals corresponding to the diet enriched with synthetic antioxidants, although significant differences were only observed at months 3 and 6 when compared to individuals belonging to diet III.

A majority of the Western population does not consume adequate levels of $\omega 3$ fatty acids through natural dietary sources, such as fish. Consequently, a great interest has been accorded recently to the $\omega 3 / \omega 6$ ratio of foods included in the human diet. Its value has shown a great effect on the development of certain health problems (Knoch et al., 2009, Valenzuela, 2009), with a recommended ratio near $1 / 6(\omega 3 / \omega 6)$ (Simopoulos, 1997). In the present work, the $\omega 3 / \omega 6$ ratio (Table 4 ) did not provide differences as a consequence of the dietary antioxidants provided or the frozen storage time. In all cases and throughout the whole storage period, $\omega 3 / \omega 6$ values obtained can be considered very positive for maintaining a balanced $\omega 3 / \omega 6$ ratio.

\section{CONCLUSIONS}

A comparative study on the nutritional value of frozen farmed coho salmon was achieved, taking into account the effect of employing diets enriched with natural antioxidants. As a result, the employment of a tocopherol-rich mixture (diet II) has led to frozen samples showing higher contents of sarcoplasmic proteins and $\gamma$ - and $\delta$-tocopherols when compared to their counterparts previously fed with a diet enriched with synthetic antioxidants (diet I). However, no effect of the antioxidant profile could be depicted in the proximate composition, $\alpha$-tocopherol and astaxanthin contents or color $\left(\mathrm{L}^{*}, \mathrm{a}^{*}, \mathrm{~b}^{*}\right)$ parameters. Concerning the fatty acid composition, individuals corresponding to diet II showed higher C22:6 13 and MUFA contents, but lower C20:5 13 and SFA contents when compared with their counterparts belonging to diet I. Differences found between frozen individuals belonging to both diets enriched with natural antioxidants were scarce, only accounting for higher $\delta$-tocopherol and DHA contents in individuals corresponding to diet II.

Further research focusing on the employment of diets enriched with natural antioxidants (diets II and III) is to be continued. As a first step, optimization of the tocopherol-rich mixture is to be achieved in order to obtain an enhancement of shelf life time, sensory acceptance and nutritional value of the frozen product.

\section{ACKNOWLEDGEMENTS}

The authors wish to thank EWOS Innovation Research (Colaco, Puerto Montt, Chile), Prof. Julia Vinagre Leiro and Miss Karina Araus for their highly valuable help. The research was carried out according to the Chilean-Spanish Cooperation Program "Universidad de Chile-Consejo Superior de Investigaciones Científicas (CSIC)" (Project CSIC-22/05-05 and Project 2004 CL 0038, respectively) and funded by the Domeyko Project 2010-VID-Universidad de Chile.

\section{REFERENCES}

Amanatidou A, Schlüter O, Lemkau K, Gorris L, Smid E, Knorr D. 2000. Effect of combined application of high pressure treatment and modified atmospheres on the shelf life of fresh Atlantic salmon. Innov. Food Sci. Emerg. Technol. 1, 87-98.

AOAC. 1990. Official Methods of Analysis of the Association of Analytical Chemistry. $15^{\text {th }}$ ed. Association of Official Chemists, Inc., Arlington, VA, USA, pp. 931-935.

AOCS. 1993. Official Methods and Recommended Practices of the American Oils Chemists' Society. $4^{\text {th }}$ ed. AOCS Press, Champaign, IL, USA, cd 18-19, pp. 1-2.

Ashie I, Smith J, Simpson B. 1996. Spoilage and shelflife extension of fresh fish and shellfish. Crit. Rev. Food Sci. Nutr. 36, 87-121.

Aubourg S, Pérez-Alonso F, Gallardo JM. 2004. Studies on rancidity inhibition in frozen horse mackerel (Trachurus trachurus) by citric and ascorbic acids. Eur. J. Lipid Sci.Technol. 106, 232-240.

Aubourg S, Rey-Mansilla M, Sotelo C. 1999. Differential lipid damage in various muscle zones of frozen hake (Merluccius merluccius). Z. Lebensm. Unters. Forsch. 208, 189-193.

Aubourg S, Medina I, Gallardo JM, Pérez-Martín R. 1995. Efecto del enlatado en aceite y salmuera y su posterior almacenamiento sobre los lípidos de la bacoreta (Euthynnus alletteratus). Grasas Aceites 46, 77-84.

Benzce Rørå A, Ruyter B, Skorve J, Berge K, Slinning K. 2005. Influence of high content of dietary soybean oil on quality of large fresh, smoked and frozen Atlantic salmon (Salmo salar). Aquac. Internat. 13, 217-223.

Bligh E, Dyer W. 1959. A rapid method of total extraction and purification. Can. J. Biochem. Physiol. 37, 911-917.

Brannan R, Erickson M. 1996. Quantification of antioxidants in channel catfish during frozen storage. J. Agric. Food Chem. 44, 1361-1366.

Castrillón A, Álvarez-Pontes E, García M, Navarro P. 1996. Influence of frozen storage and defrosting on 
the chemical and nutritional quality of sardine (Clupea pilchardus). J. Sci. Food Agric. 70, 29-34.

Choubert G, Baccaunaud M. 2006. Colour changes of fillets of rainbow trout (Oncorhynchus mykiss W.) fed astaxanthin or canthaxanthin during storage under controlled or modified atmosphere. Lewensm. Wiss. Technol. 39, 1203-1213.

Christophersen A, Bertelsen G, Andersen H, Knuthsen P, Skibsted L. 1992. Storage life of frozen salmonids. Effect of light and packaging conditions on carotenoid oxidation and lipid oxidation. Z. Lebensm. Unters. Forsch. 194, 115-119.

Erickson M. 1997. Lipid oxidation: Flavor and nutritional quality deterioration in frozen foods, in Erickson $M$, Hung Y-C (Eds.) Quality in Frozen Food. Chapman \& Hall, New York, USA, pp. 141-173.

Gobantes I, Choubert G, Gómez R. 1998. Quality of pigmented (astaxanthin and canthaxanthin) rainbow trout (Oncorhynchus mykiss) fillets stored under vacuum packaging during chilled storage. J. Agric. Food Chem. 46, 4358-4362.

Hamre K, Berge R, Lie O. 1998. Oxidative stability of Atlantic salmon (Salmo salar, L.) fillet enriched in $\alpha-$, $\gamma$ - and $\delta$ - tocopherol through dietary supplementation. Food Chem. 62, 173-178.

$\mathrm{He}$ P, Ackman R. 2000. HPLC determination of ethoxyquin and its major oxidation products in fresh and stored fish meals and fish feeds. J. Sci. Food Agric. 80, 10-16.

Holaas E, Bohne V, Hamre K, Arukwe A. 2008. Hepatic retention and toxicological responses during feeding and depuration periods in Atlantic salmon (Salmo salar) fed graded level of the synthetic antioxidant, butylated hydroxytoluene. J. Agric. Food Chem. 56, 11540-11549.

Hwang D, Lin J, Cheng H. 1995. Level of synthetic antioxidant in cultured fish and fish feed. J. Food Drug, Anal. 3, 27-32.

Jensen C, Birk E, Jokumsen A, Skibsted L, Bertelsen G. 1998. Effect of dietary levels of fat, alpha-tocopherol and astaxanthin on colour and lipid oxidation during storage of frozen rainbow trout (Oncorhynchus mykiss) and during chill storage of smoked trout. $Z$. Lebensm. Unters. Forsch. 207, 189-196.

Knoch B, Barnett M, Roy N, McNabb W. 2009. Study of the effects of dietary polyunsaturated fatty acids: Molecular mechanisms involved in intestinal inflammation. Grasas Aceites 60, 8-21.

Lugasi A, Losada V, Hóvári J, Lebovics V, Jakóczi I, Aubourg S. 2007. Effect of pre-soaking whole pelagic fish in a plant extract on sensory and biochemical changes during subsequent frozen storage. Lewensm. Wiss. Technol. 40, 930-936.

Lundebye K, Hove H, Mage A, Bohne V, Hamre K. 2010. Levels of synthetic antioxidants (ethoxyquin, butylated hydroxytoluene and butylated hydroxyanisole) in fish feed and commercially farmed fish. Food Additives \& Contaminants: Part A: Chemistry, Analysis, Control, Exposure \& Risk Assessment 27, 1652-1657.

Mackie I. 1993. The effects of freezing on flesh proteins. Food Rev. Internat. 9, 575-610.

Medina I, Gallardo JM, Aubourg S. 2009. Quality preservation in chilled and frozen fish products by employment of slurry ice and natural antioxidants. Int. J. Food Sci. Technol. 44, 1467-1479.

Ortiz J, Larraín MªA, Vivanco JP, Aubourg S. 2009. Rancidity development during the frozen storage of farmed coho salmon (Oncorhynchus kisutch): Effect of antioxidant composition supplied in the diet. Food Chem. 115, 143-148.

Ortiz J, Palma Ó, González N, Aubourg S. 2008. Lipid damage in farmed rainbow trout (Oncorhynchus mykiss) after slaughtering and chilled storage. Eur. J. Lipid Sci. Technol. 110, 1127-1135.

Perea A, Gómez E, Mayorga Y, Triana C. 2008. Nutritional characterization of produced fish for human consumption in Bucaramanga, Colombia. Archivos Latinoamericanos de Nutrición 58, 91-97.

Piñeiro C, Barros-Velázquez J, Pérez-Martín R, Martínez I, Jacobsen $T$, Rehbein $H$, Kündiger R, Mendes R, Ettienne M, Jerome M, Craig A, Mackie I, Jessen F. 1999. Development of a sodium dodecyl sulfatepolyacrylamide gel electrophoresis reference method for the analysis and identification of fish species in raw and heat-processed samples: A collaborative study. Electrophoresis 20, 1425-1432.

Sheehan E, O'Connor T, Sheehy P, Buckley D, Fitzgerald R. 1998. Stability of astaxanthin and canthaxanthin in raw and smoked Atlantic salmon (Salmo salar) during frozen storage. Food Chem. 63, 313-317.

Sigurgisladóttir S, Parrish C, Ackman RG, Lall S. 1994. Tocopherol deposition in the muscle of Atlantic salmon (Salmo salar). J. Food Sci. 59, 256-259.

Simopoulos A. 1997. Nutritional aspects of fish, in Luten J, Börrensen T, Oehlenschläger J (Eds.) Seafood from Producer to Consumer, Integrated Approach to Quality. Elsevier Science, London, UK, pp. 589-607.

Stéphan G, Guillaume J, Lamour F. 1995. Lipid peroxidation in turbot (Scophthalmus maximus) tissue: Effect of dietary vitamin $E$ and dietary $n-6$ or $n-3$ polyunsaturated fatty acids. Aquaculture 130, 251-268.

Stodolnik L, Stawicka A, Grzegorz G, Aubourg S. 2005. Rancidity inhibition study in frozen whole mackerel (Scomber scombrus) following flaxseed (Linum usitatissimum) extract treatment. Grasas Aceites 56, 198-204.

Taheri S, Fazlara A, Motallebi A, Aftabsavar Y, Aubourg S. 2012. Effect of previous ascorbic acid treatment on fatty acid profile in cobia (Rachycentron canadum) fillets during frozen storage. Grasas Aceites 63, 7078.

Tironi V, Tomás M, Añón MC. 2010. Quality loss during the frozen storage of sea salmon (Pseudopercis semifasciata). Effect of rosemary (Rosmarinus officinalis) extract. Lewensm. Wiss. Technol. 43, 263272.

Undeland I, Hultin H, Richards M. 2003. Aqueous extracts from some muscles inhibit hemoglobinmediated oxidation of cod muscle membrane lipids. J. Agric. Food Chem. 51, 3111-3119.

Valenzuela A. 2009. Docosahexaenoic acid (DHA), an essential fatty acid for the proper functioning of neuronal cells: their role in mood disorders. Grasas Aceites 60, 203-212.

Vinagre J, Rodríguez A, Larraín Mª̣, Aubourg S. 2011. Chemical composition and quality loss during technological treatment in coho salmon (Oncorhynchus kisutch). Food Res. Internat. 44, 1-13.

Waagbø R, Sandnes K, Torrisen O, Sanvin A, Lie $\varnothing$. 1993. Chemical and sensory evaluation of fillets from Atlantic salmon (Salmo salar) fed three levels of $n-3$ polyunsaturated fatty acids at two levels of vitamin $\mathrm{E}$. Food Chem. 46, 361-366. 